River Research and Applications

WILEY

\title{
An assessment of variants in the professional judgement of geomorphologically-based channel types
}

\begin{tabular}{|r|l|}
\hline Journal: & River Research and Applications \\
\hline Manuscript ID: & RRA-10-0179.R2 \\
\hline Wiley - Manuscript type: & Research Article \\
\hline Date Submitted by the \\
Author: & n/a \\
\hline Complete List of Authors: & $\begin{array}{l}\text { Milner, Victoria; University of Worcester, Institute of Science and } \\
\text { the Environment } \\
\text { Gilvear, Gilo; University of Stirling } \\
\text { Willby, Nigel; University of Stirling, Centre for River Ecosystem } \\
\text { Science, Institute of Biological and Environmental Sciences }\end{array}$ \\
\hline Keywords: & $\begin{array}{l}\text { channel type, professional judgement, river classification, channel } \\
\text { morphology }\end{array}$ \\
\hline
\end{tabular}

\section{SCHOLARONE ${ }^{m}$ Manuscripts}




\title{
AN ASSESSMENT OF VARIANTS IN THE PROFESSIONAL JUDGEMENT OF GEOMORPHOLOGICALLY-BASED CHANNEL TYPES
}

\author{
VICTORIA S. MILNER ${ }^{\mathrm{a}}$, DAVID J. GILVEAR ${ }^{\mathrm{b}}$ AND NIGEL J. WILLBY ${ }^{\mathrm{b}}$ \\ ${ }^{a}$ Institute of Science and the Environment, University of Worcester, Henwick Grove, Worcester, WR2 \\ $6 A J, U K$ \\ ${ }^{b}$ Centre for River Ecosystem Science, Institute of Biological and Environmental Sciences, University of \\ Stirling, Stirling, FK9 4LA, UK
}

\begin{abstract}
River classification is a useful tool for researchers and managers wishing to organise, simplify and understand the forms and processes within freshwater systems. Many classifications require surveyors to classify reaches into specific channel types in a field environment. Channel types should be identifiable based on a field surveyor's judgement of channel characteristics and landscape settings; these include channel planform, valley confinement, dominant bed material, and/or instream geomorphic features (e.g. gravel bars). Accurate classification of reaches into the correct channel type is important to ensure consistency in management strategies, and to assess the impact of engineering activities on the physical and ecological status of rivers. In this paper, we examine the variation in professional judgement of geomorphologicallybased channel types by scientists with different disciplinary backgrounds, and varying levels of involvement in classification systems using a photo-questionnaire. Results indicate that there can be a large level of discrepancy in typing rivers; the choice of the modal channel type for each reach varied between $25.9 \%$ and $75.1 \%$ of the respondent selections. There were also differences in the level of agreement between earth scientists (with hydrogeomorphological or geological training), ecological scientists (with freshwater biology training) and practitioners involved in river conservation and management. A high level of experience in classification systems translates to a lower number of channel types being chosen per reach. In response to these results, the use of a photographic approach to typing needs to be fully tested and users fully trained before operational use. Furthermore, we advocate that designers of geomorphic typologies should aim to have a representative and workable number of classes within a typology with an emphasis for rationalisation of classes rather than expansion of numbers.
\end{abstract}

KEY WORDS: channel type; professional judgement; river classifications; river typologies; channel morphology.

\section{INTRODUCTION}

A large number of classifications and typologies have been developed in fluvial geomorphology since the late $19^{\text {th }}$ century. The numerous approaches to classifications and typologies reflect the wide range of disciplines, the large number and variety of variables used, different objectives for which the systems were designed, and the challenge of simplifying complex, diverse, natural systems (Kondolf, 1995; Juracek and Fitzpatrick, 2003; Kondolf et al., 2003). The identification of channel types in many classification systems relies on a field surveyor's judgement of channel characteristics, such as channel planform, valley confinement, dominant bed material and geomorphic units. An early example of 
channel typing is Leopold and Wolman's (1957) classification of straight, meandering and braided channel patterns based on relationships between slope and discharge. This pattern based approach was later expanded to include anastomosing channels (Smith and Smith, 1980; Knighton and Nanson, 1993; Makaske, 2001), and also anabranching channels (Nanson and Knighton, 1996). In Canada, Kellerhals et al., (1972, 1976), Galay et al., (1973) and Mollard (1973) have proposed very descriptive classification systems for describing a wide range of stream morphologies using a combination of channel patterns, channel islands and bars, and degree of lateral channel mobility to define a variety of channels. Other notable examples include the Montgomery and Buffington $(1997,1998)$ typology, and the River Styles Framework of Brierley and Fryirs (2000, 2005).

In the UK, the Scottish Environment Protection Agency (SEPA) and the Environment Agency (EA) are now using a tool (termed the Morphological Impact Assessment System: MImAS; Greig et al., 2006) to assess the geomorphic sensitivity of channel morphology to engineering pressures, which is based upon correct identification of a reach to a channel type. The channel typology is a modified version of the processbased typology developed by Montgomery and Buffington $(1997,1998)$ in the Pacific Northwest of the USA (see Figure 1 for Montgomery and Buffington typology, 1997, 1998). Additional channel types have been added to include lowland environments, characteristic of the UK. The underlying principle of the typology is that channel types occur in areas with differing sets of geomorphological controls. The typology comprises eleven distinct channel types (Table 1). The allocation of a reach to the correct parent channel type is critical to the accuracy of the tool, and in assessing the impact of engineering activities on the physical and ecological status of rivers.

The principal aim of this paper is to assess whether single photographs of a riverine landscape are an adequate technique for classifying stream types. This aim will be explored by comparing the perception of channel types in the SEPA typology by scientists with different backgrounds and varying levels of involvement in classification systems using a photo-questionnaire. Channel types in the SEPA typology should be identifiable based on a combination of channel planform, typical bed material, bedform pattern, dominant roughness elements, valley confinement and geomorphic units. The research hypotheses associated with the principal aim are:

- Earth scientists (with hydromorphological or geological training) have a lower level of disagreement in the identification of individual channel types compared to ecological scientists and practitioners involved in river conservation and management.

- A high level of involvement in river classification systems translates to a lower level of disagreement in the identification of individual channel types.

In addition, a short experiment was carried out to assess the extent to which a short training programme could reduce the diversity of opinion among respondents when classifying a reach. It is believed that this paper represents the first attempt to quantify the accuracy of individuals to identify channel types.

\section{METHODS}

The assessment of landscape perception in river environments using photographs is a well known approach (Mosley, 1989; Brown and Daniel, 1991; Gregory and Davis, 1993), and is preferable to directly showing large numbers of participants to a wide 
range of sites separated by large geographical distances (Shuttleworth, 1980). A photograph is a two-dimensional image whose content cannot capture the dynamics and complexities of river systems, such as sound and movement (Huang and Tassinary, 2000), and hence is different from on-site experience, but it fulfils the purposes for an analysis, principally a surrogate of presentation to the respondents (LeLay et al. 2008). Photographs offer control over environmental stimuli and permit rapid and widespread sampling of environments (Hull and Stewart, 1992). Several studies have explored the perception of observers in the field to ground photographs, and have shown no statistical difference between the two methods (Shuttleworth 1980; Vining and Orland, 1989). As such, using photographs in a photographic questionnaire was viewed as an acceptable method to identify the perception of channel types in the SEPA typology by a range of participants. Accurate classification of channel types using photographs would be beneficial for managers and researchers as the approach would reduce the amount of fieldwork and decrease costs.

A questionnaire with photographs of nineteen river sub-reaches/reaches (see Figure 2) was advertised and circulated to delegates at a workshop, 'Defining hydromorphological condition and links to ecology', in Ballater, Scotland in March 2009, and at the 'First Triennial Symposium for the International Society of River Science (ISRS)', in St Petersberg, Florida, USA in July 2009. The photoquestionnaire was also available online on a website (http://www.sbes.stir.ac.uk/ people/postgrads/milner/questionnaire). The photo-questionnaire contained four background questions relating to a respondent's discipline, affiliated organisation, level of involvement in classification systems, and geographic region. A wide range of disciplines and job titles were specified from the respondents who conducted the questionnaire. These were categorised as earth scientists, ecological scientists and practitioners involved in river conservation and management for simplicity. Similarly, categories relating to a respondent's level of involvement in classification systems was amalgamated from extensive, significant, moderate, limited and none into three broad categories of high (extensive or significant), moderate and low (limited or none).

A respondent was requested to classify each reach into one of eleven channel types inherent within the SEPA typology. A description of each channel type was also included in the photo-questionnaire (Table 1). The classification of reaches into channel types was also determined by the averaged expert opinion of three professional fluvial geomorphologists: Dr Richard Jeffries, a senior hydromorphologist at SEPA, Professor David Gilvear, the University of Stirling and Dr Victoria Milner, the postgraduate student who conducted this research at the University of Stirling. All three fluvial geomorphologists have been involved with testing and applying the SEPA typology to the Scottish fluvial environment, and are familiar with the river systems used.

A short experiment was carried out to investigate if a short training programme could reduce the diversity of opinion among respondents when classifying a reach. A group of Masters students in Environmental and River Basin Management at the University of Stirling were asked to conduct the photo-questionnaire. Subsequently, the students attended a three hour tutorial relating to the background of classification systems, fluvial forms and processes. This included a discussion of how to classify the channel 
types in the SEPA typology using a channel typology flow diagram (Figure 3). Post training, the students were asked to re-take the questionnaire.

The photographs used in the questionnaire were obtained from a wider study, which assesses the performance of morphologically-based river typing in Scotland using a geomorphological and ecological approach (Milner, 2010). Of the 200 photographs of reaches used in the mentioned study, 50 were downloaded for a final selection by the professional geomorphologists. Pictures were removed from the selection if scenes were deemed inappropriate for the survey (e.g. containing man-made structures or views that obscured key geomorphic elements of that channel type). Nineteen pictures were agreed upon by the professional geomorphologists in the group. For some channel types, such as for braided or wandering reaches, a single photograph was judged to be insufficient to portray the full range of characteristics of the more complex channel types, so a second photograph was included. One photograph aimed to show an overview of the planform of the reach, and a second photograph focused in on the geomorphic attributes and/or the hydraulics within the reach, such as the presence of depositional bars or the occurrence of pools and riffles. In contrast, the characteristics of a plane-bed reach, for example, may be encapsulated in one photograph. Plane-bed reaches are single channels with for the most part a planar gravel and cobble-bed (Florsheim, 1985), which lack discrete bars that are often related to low width to depth ratios (Sukegawa, 1973; Ikeda, 1975, 1977). This range of characteristics can be easily captured by one photograph.

\section{Data analysis}

Data from the photo-questionnaire was input into Excel with the respondents' raw data tabulated and checked for errors. The Shapiro-Wilk's (S-W) statistical test was applied to test the data's frequency distribution for normality, and a log transformation was used where necessary. A paired t-test (Minitab version 15.1) was performed to test if the mean number of channel types chosen per reach was statistically different, between respondents from various disciplines, and respondents with different amounts of experience in classification systems. A paired t-test was also conducted on the average percentage of respondents selecting the most common channel types per reach, between disciplines, and respondents with different levels of experience in classification systems. Lastly, a paired t-test was performed on the results of the photo-questionnaire undertaken by the group of students, pre and post training.

Principal Components Analysis (PCA) (CANOCO version 4.5, ter Braak and Šmilauer, 1998), was carried out on the probability of a channel type been selected by a respondent. In PCA, linear combinations of the original variables are created that express the maximum amount of variability in the original dataset (Scott and Clarke, 2000). The first principal component (PC) axis (or new variable) accounts for the maximum amount of data variability possible in a single variable, and successive PCs axes explain as much as possible of the residual variance (Scott and Clarke, 2000). The kappa statistic ('Online Kappa Calculator' of Randolph, 2008) was also used as a method to determine the level of agreement among respondents regarding the number and range of channel types selected per reach. The kappa statistic is a technique that measures agreement between categorical variables after correction that is expected to occur due to chance (Siegel and Castellan, 1988). The kappa statistic can be used on any number of cases (i.e. study reaches), categories (i.e. channel types) or number of 
respondents. A value of kappa ranges from -1.0 to 1.0 , with -1.0 denoting perfect disagreement below chance and 1.0 denoting perfect agreement above chance (Randolph, 2008). A kappa of $>0.7$ indicates adequate agreement among the respondents (Randolph, 2008). In this study, the free-marginal kappa of Brennan and Prediger (1982) was used, as this version of the statistic allows respondents to select any category (i.e. channel type) for any case (i.e. study reach). Finally, a braided index (BI, proposed by Howard et al. 1970) was calculated for specific reaches possessing numerous mid-channel bars and channels, as a measure of network complexity. This BI provides a simple count of the total number of links (or segments, $<\mathrm{N}_{\mathrm{L}}>$ ) in the measured reach (Egozi and Ashmore, 2008).

\section{RESULTS}

A total of 205 professionals involved in river science and/or river management responded to the photo-questionnaire. Of the total number of respondents, $42 \%$ were earth scientists, $32 \%$ were ecological scientists, and $26 \%$ were practitioners involved in river conservation and management. A large proportion of respondents had a moderate $(39 \%)$ or low level $(47 \%)$ of experience in classification systems, with few respondents possessing a high amount of experience in classification systems (14\%).

The percentage of channel types chosen per reach is illustrated in Table 2. The channel type with the highest percentage of respondents per reach represents the most common channel type chosen, and is regarded as the "global view" of the respondents. For example, the most common channel type chosen for Photograph A is a low gradient actively meandering channel. Therefore, Photograph A will now be designated as a low gradient actively meandering channel. The Kappa statistic was performed on the data in Table 2, and generated a free-marginal kappa value of 0.27. This statistic is below the critical value of 0.7 , which denotes adequate agreement among the respondents. Instead, the kappa value is closer to 0 , indicative of agreement equal to chance. The output of the kappa technique highlights a large variation in responses regarding the selection of channel types per reach. A kappa value of 0.27 would nominally reveal a moderate-poor level of agreement in classification between respondents.

The range in the percentage of respondents choosing the most common channel type varies from $25.4 \%$ for photograph J, a plane-riffle channel to $75.1 \%$ for photograph C, a braided channel (Table 2). The results imply that some individual channel types may be easier to identify than others. However, taking account of both the first and second most commonly voted types in each photograph, only three of the nineteen pictures showed $>50 \%$ of the votes split across more than three possible channel types. Based on the results in Table 2, an average percentage of respondents choosing a specific channel type was calculated (Table 3). Bedrock channels, particularly the reach in Photograph $G$ appear the most readily identifiable. Similarly, braided channels are also identifiable, especially the reach in Photograph C. Plane-riffle reaches seem to be the most difficult channel type to classify, indicated by a low average of respondents $(27.2 \%)$.

A Principal Components Analysis (PCA) was conducted on the percentage of a channel type being chosen by the respondents. The majority of the variation in the PCA model is summarised by the first two PCs (cumulative percentage variance 58). 
Therefore, further analysis will focus on these two PC axes. An accompanying PCA bi-plot for these two PC axes is shown in Figure 4. The arrows denote the channel types, and the circles indicate the position of the nineteen photographs (A to S). The arrows denote an increasing percentage of a respondent selecting a channel type. Thus, photographs positioned near the arrowhead will have a high percentage of being selected, compared to a photograph located near the centre of the bi-plot. The positioning of a photograph also reveals the diversity of opinions among the respondents regarding the classification of a reach. A high percentage of respondents (75.1\%, Table 2) classified the reach in photograph $\mathrm{C}$ as braided. The reach in photograph L was also classified as braided, but fewer respondents (37.6\%, Table 2) opted for this channel type. A substantial number of respondents (24.9\%, Table 2) also selected a wandering channel for this reach. The difference in the agreement between the reaches in photographs $\mathrm{C}$ and $\mathrm{L}$ is reflected in the positioning of the circles in the PCA bi-plot.

The responses of the participants who conducted the questionnaire were compared to the responses of the three professional geomorphologists (Table 4). The respondents agree with the professional geomorphologists for eleven of the nineteen reaches. The two groups tend to agree regarding the characteristics of a low gradient actively meandering channel (both classified photographs A, D and R as a low gradient actively meandering reaches), and a step-pool channel (both groups selected step-pool channel for photographs $\mathrm{B}, \mathrm{K}$ and $\mathrm{S}$ ). Disagreement existed concerning the classification of braided and wandering reaches. The professional geomorphologists classified the reach in photographs $\mathrm{C}, \mathrm{I}$ and $\mathrm{L}$ as a wandering channel, whereas the majority of respondents believed the reaches are braided.

The level of disagreement among earth scientists, ecological scientists and practitioners involved in river conservation and management has been measured by the number of channel types selected per reach, and the percentage of respondents agreeing with the most common channel type per reach. Table 5 illustrates the number of channel types chosen per reach by respondents from different disciplines. Overall, the lowest number of channel types chosen is for the reach in photograph $\mathrm{K}$, a steppool channel, and the highest number of channel types selected is for the reach in photograph J, a plane-riffle channel. Clear statistical differences were present between earth scientists and practitioners involved in river conservation and management (paired $t$-test $P$-value of $<0.001$ ), and also between ecological scientists and practitioners involved in river conservation and management (paired $t$-test of $P$-value $<0.038$ ). No statistical difference was apparent in the number of channel types selected per photograph between earth and ecological scientists (paired $t$-test $P$-value of $<0.094)$.

Although, earth scientists selected a higher number of channel types per reach compared to ecological scientists and practitioners involved in river conservation and management, the former group had a statistically higher percentage of respondents agreeing with the most common channel type per reach (paired $t$-test $P$-value of 0.048 and 0.009 respectively; Table 6). No statistical difference existed between the mean numbers (46.4 and 46.8) of ecological scientists or practitioners involved in river conservation and management choosing the dominant channel type (paired $t$-test $P$ value of 0.89 ). 
The number of channel types chosen per reach by respondents with different levels of experience in classification systems is shown in Table 7. Respondents possessing a high level of experience in classification systems have the lowest overall average for the number of channel types selected per reach. Respondents possessing moderate and low levels of experience in classification systems have a higher average for the number of channel types chosen per reach. A paired t-test highlighted the means were statistically different between all three groups $(P$-value for all combinations of groups $<0.001$ ). Table 8 shows the most common channel type chosen per photograph by respondents with different levels of experience in classification systems. The three groups of respondents (based on level of experience: high, moderate and low) selected the same channel type for ten of the nineteen rivers and streams (photographs A, B, C, $\mathrm{E}, \mathrm{G}, \mathrm{H}, \mathrm{K}, \mathrm{O}, \mathrm{R}$ and $\mathrm{S}$ ). No reach has more than two different dominant channel types. A paired t-test identified a statistical difference in mean values between the dominant channel type chosen by respondents possessing a high and low level of experience (paired t-test $P$-value of 0.015 ).

The results show a high level of experience in classification systems corresponds to a statistically lower number of channel types chosen per reach. This statement is supported by the results of the short experiment undertaken on a group of $16 \mathrm{MSc}$ students to identify if a training programme could improve the level of agreement among respondents when classifying reaches. A group of MSc students at the University of Stirling were asked to conduct the photo-questionnaire, pre and post training. A paired t-test ( $P$-value of 0.005$)$ revealed a statistically lower number of channel types per reach were chosen post completion of a training programme. The short experiment indicates how a simple training programme can increase the accuracy of classifying reaches. Therefore, a training programme focussing on the dominant characteristics of the channel types in the SEPA typology (or channel types in any geomorphic classification or typology) may improve a respondent's accuracy of classifying reaches. The reaches in photographs $A, C, G, I, O$ and $R$ all have relatively high percentages of being chosen by a respondent (Table 2). Therefore, the reaches could possibly be used as a benchmark for the channel type they most represent. A high percentage of respondents $(75.1 \%$, Table 2$)$ classified the reach in photograph $\mathrm{C}$ as a braided reach. Thus, this reach could be used as an example of a braided reach, and be included in training documentation. The reach in photograph $\mathrm{L}$ was also classified as a braided reach, but fewer respondents (37.6\%, Table 2) opted for this channel type. A notable number of respondents (24.9\%, Table 2) selected a wandering reach. The difference in the agreement between reaches being classified as braided or a wandering reach may reflect a change in the specific characteristics of a reach been viewed as typical of a braided or wandering reach. Where the number of respondents is approximately equal between the classification of two channel types, this may represent the reach being a transitional between two types. For example, the higher percentage of respondents opting for a wandering reach for photograph $L$ than $\mathrm{C}$ suggests that the reach in photograph $\mathrm{C}$ may be a transition between fully braided and classically wandering. The change in the characteristics of a reach from a typical braided reach to possessing attributes of a wandering reach is shown in Photographs C, I and L in Figure 2. Photograph C has a Braided Index (BI) of 18, Photograph I possess a BI of 4 , and Photograph L has a BI of 3. The BI scores for the three reaches support the earlier statement that the photographs show a continuum of changes in the key characteristics from one channel type (braided) to another channel type (wandering). Awareness of the fact that individual channel types can demonstrate 
different morphologies along a continuum is likely to be useful in educational programmes aimed at improving the accuracy of classification.

\section{DISCUSSION}

The approach used in this paper uses sub-reach and reach scale photographs in a webbased questionnaire to judge if single photographs of a landscape are an adequate technique for classifying stream reaches. This aim was explored by identifying the perception of channel types in a typology by scientists from a range of disciplines, and with different levels of involvement in classification systems. Photographs have often been used in questionnaires or surveys to gauge public or scientific perception. For example, Piegay et al., (2005) and Le Lay et al., (2008) used a photo-questionnaire to assess variations in public perception as a barrier to introducing wood in rivers for restoration purposes. Mosley (1989) also used photographs to obtain views of New Zealand river scenery from different groups of respondents, such as canoeists, anglers, landscape architects and government staff. However, a photo-questionnaire has not been known to assess the perception of channel types.

The percentage of respondents selecting the most common channel type per reach varies from $25.4 \%$ to $75.1 \%$ (Table 2), which implies the difficulty of classifying a reach into a specific channel type varies depending on the characteristics of the reach. The percentage of the most common channel type chosen per reach was averaged according to channel type (i.e. into bedrock, plane-bed; Table 3). The results revealed that bedrock reaches (possessing an average of $69.8 \%$, Table 3 ) emerge as the single most identifiable channel type. Bedrock channels are characterised by either a predominance of exposed bedrock or have a thin, sporadic accumulation of alluvium (Montgomery and Buffington, 1998). The fast velocities generally associated with a high transport capacity are indicative of a combination of surface flow types (SFTs), particularly chute flow, broken standing and unbroken standing waves (Milner, 2010) The dominance of exposed bedrock, lack of alluvium and high energy SFTs contribute to bedrock channels possessing distinct characteristics, and thus, are relatively easy to identify for surveyors or respondents. Braided reaches also have a relatively high percentage of correct identification (57\%, Table 3). Braided reaches are characterised by having numerous alluvial channels with bars or islands, repeatedly joining and dividing (Leopold and Wolman, 1957; Lane, 1957). This distinct morphology aids respondents to easily recognise a braided channel. In contrast, plane-riffle channels have a very low rate of correct identification $(27.2 \%$, Table 3). A plane-riffle channel is a transitional reach between a plane-bed and a pool-riffle channel, possessing attributes of both types (Greig et al., 2006). Planeriffle reaches tend to be on gentler gradients have a greater range of velocities compared to plane-bed reaches, and have less defined pools, armoured substrate, and less extensive bar features compared to pool-riffle reaches. The transitional characteristics of this channel type may explain why respondents may misclassify a plane-riffle reach as a plane-bed or a pool-riffle channel. A distinguishing feature of plane-riffle reaches is the sequence of a smooth flow and unbroken standing waves, symptomatic of glides and riffles. The identification of these SFTs is difficult to identify from a photograph, and is more apparent in the field. This may partly account for the low percentage of respondents classifying reaches as a plane-riffle channel in this photographic-based analysis. 
The respondents and professional geomorphologists matched the same channel type for eleven of the nineteen photographs. Two of the professional geomorphologists (Dr V.S. Milner and Professor D.J. Gilvear) have extensively visited and surveyed all the reaches in the photographs. Consequently, their choice of type may be influenced by their field visits. Both fluvial geomorphologists have the advantage of viewing the reaches in relation to the valley setting, and observing the reaches' surface flow patterns and geomorphic units. Valley confinement, width of floodplain, and differing and repeating combinations of SFTs and geomorphic units all aid a surveyor in classifying a reach to a channel type. The professional geomorphologists' field visits may partly explain the difference in opinion between their view of a channel types and the view of respondents with high levels of experience in classification. Another issue is the influence of scale, angle of photograph and flow conditions at the time of capture. Standard protocols for taking photographs may need to be produced. For example, it could be suggested that surveyors capture a reach that approximates to a scale of 20 channel widths. Although, a photographer may find it not possible to capture the length of the reach (20 channel widths) in a single photograph either due to steep gradients or the meandering planform of certain reaches. Furthermore, a photograph capturing the reach at that scale may not be sufficiently detailed to illustrate the morphological subtleties and features characteristic of that specific channel type. Hence, in practice adhering to such protocols may be problematic. The photographs at the sub-reach/reach scale were taken during low flow conditions, so the morphological features indicative of a channel type were visually apparent to aid classification. A single channel type however, will have different hydraulic characteristics, as well as exhibiting different channel forms at low, medium and high flows. For example, steps and pools are symptomatic of step-pool sequences but can be drowned out under high flows.

The channel types in the SEPA typology are partly based on the morphological response to the relative ratio of sediment supply to transport capacity, and also on channel pattern and characteristics. Channel types should be distinguished by typical bed material, bedform pattern, dominant roughness elements, primary sediment sources and sediment storage elements, typical confinement, and typical pool spacing (channel widths) (Montgomery and Buffington, 1997). The underlying principle of classification is that channel morphology is the collective product of a number of interacting variables (Kellerhals et al., 1976; Kellerhals and Church, 1989; Thorne, 1997; Eaton et al., 2004), such as the volume and time distribution of water from upstream, the volume, timing and character of sediment transported to the channel, the materials through which the river flows, the local geological history and the topographic gradient of the landscape (Church, 1992; Church, 2002, Robert, 2003). Earth scientists, such as hydrologists and particularly fluvial geomorphologists ought to have a more extensive knowledge and understanding of these independent variables controlling channel morphology and form, compared to ecological scientists and other disciplines. Therefore, in theory, earth scientists should have less diversity of opinion regarding the number of channel types per reach compared to ecological scientists and practitioners involved in river conservation and management. However, the results indicate that earth scientists actually select a higher overall number of channel types per reach in contrast to the practitioner group. This may reflect a greater awareness of the range of possible channel types among earth scientists and a familiarity with key terminology, even if this is interpreted to produce a large number of types per reach. 
The number of channel types chosen per reach is statistically higher for earth scientists compared to practitioners involved in river conservation and management. However, there are a statistically higher percentage of earth scientists choosing the most common channel type per reach compared to practitioners involved in river conservation and management. The results imply that there are a relatively uniform number of practitioners choosing a few channel types per reach, whereas for earth scientists, a greater number of channel types per reach are chosen, but most of the respondents choose the same channel type. Therefore, the hypothesis that earth scientists have a lower level of disagreement in the identification of individual channel types compared to practitioners involved in river conservation and management can be accepted, but earth scientists do not have a lower level of disagreement compared to ecological scientists.

The level of involvement in classification systems corresponds to the number of channel types selected per reach (Table 7). Respondents with a high level of experience in classification systems possessed a statistically lower average for the number of channel types chosen per reach, compared to respondents with a moderate or low level of expertise in classification systems. Therefore, the more experience an individual possesses regarding working with classification systems, the less confusion exists about selecting a channel type. The results of a short experiment conducted on the perception of channel types on a group of Masters students' pre and post training supports this conclusion. In reference to this experiment, the development of guidance and methods for selecting channel types is important. The number of channel types chosen per reach, by a group of students was statistically lower post training. Hence, the research hypothesis that a high level of involvement in classification systems relates to a low number of channel types per reach can be accepted. The results definitively indicate the importance of training, knowledge and experience. The more experience a respondent possesses in fluvial systems, the greater their understanding of the processes and resulting forms of rivers and streams.

In summary, river typologies can be a highly useful management tool for practitioners and scientists. Typologies aim to organise, simplify and aid understanding of the natural forms and processes within environmental systems (Juracek and Fitzpatrick, 2003). This information can help practitioners and/or scientists to predict a river's behaviour from its appearance (Rosgen, 1994), and contribute to recommendations regarding channel maintenance, conservation and restoration issues. Indeed, restoration design has been dominated by classification schemes (Doyle et al. 1999). The SEPA typology forms an integral part of the MImAS tool (discussed in the introduction), which is used to determine the geomorphic sensitivity of channel morphology to engineering pressures. In a Scottish context therefore, identification by practitioners and scientists to the correct channel type is imperative. However, this study has highlighted the variability among respondents of differing disciplinary background and experience when classifying specific types. The study is useful for practitioners through providing an indication of the reliability in classifying channel types, and implies training programmes are essential to improve typing accuracy.

\section{CONCLUSIONS}

The results of this photo-questionnaire survey indicate that by using single photographs of river reaches for classification, there can be significant 
misclassification of channel types and that the level of disagreement varies according to the background and experience of the survey participants. One solution to reduce the variance may be to establish a protocol for photographic images in relation to channel typing, in terms of scale and flow conditions. This study also demonstrates that with guidance on the process of channel typing and training the accuracy of a respondent's classification can be improved. However, there will always be a subjective component leading to differences in classification whether using photographs or observations in the field. This knowledge is important when managers and regulators are considering the use of channel typologies for classification and assessment of rivers.

Another fundamental issue in river typology science is the number of designated classes. In designing a typology, it is easy to be led in the direction of adding more and more channel types due to the inherent morphological variability of fluvial systems along a continuum. However, this activity may decrease the levels of confidence placed in assigning individual classes. As such, we advocate a trend towards typologies where rationalisation of types is inherent.

In the future, the subjective approach of classifying reaches into channel types using photo-questionnaires or field surveys should possibly be replaced or compared to more objective, quantitative, statistical approaches, such as using GIS variables to predict channel types (Snelder et al., 1999; Snelder and Biggs, 2002) or using quantitative techniques such as cluster analysis and ordination techniques on physical habitat data (Milner, 2010). These approaches may prove more accurate and robust compared to subjective judgements of channel types based on photographs or field surveys.

\section{ACKNOWLEDGEMENTS}

This study was funded by a UK Natural Environment Research Council (NER/S/A/2006/14226) case studentship with the Scottish Environment Protection Agency. We would like to thank Dr R. Jeffries for helping classify the study reaches, and for granting permission to use the channel typology flow diagram. The views expressed in this paper reflect those of the authors and not that of the institutions they represent. 


\section{References}

Brennan RL, Prediger DJ. 1981. Coefficient Kappa: Some uses, misuses, and alternatives. Educational and Psychological Measurement 41: 687-699.

Brierley GJ, Fryirs K. 2000. River Styles, a Geomorphic Approach to Catchment Characterization: Implications for River Rehabilitation in Bega Catchment, New South Wales, Australia. Environmental Management 25 (6): 661-679.

Brierley GJ, Fryirs KA. 2005. Geomorphology and River Management. Applications of the River Styles Framework. Blackwell Publications: Oxford.

Brown TC, Daniel TC. 1991. Landscape aesthetics of riparian environments: Relationships of flow quantity to scenic quality along a wild and scenic river. Water Resources Research 27(8): 1787-1795.

Church M. 1992. Channel morphology and typology In Calow P. and Petts G (Eds) The Rivers Handbook: Hydrological and Ecological Principles, Oxford, Blackwell Scientific Publications: 126-143.

Church M. 2002. Geomorphic thresholds in riverine landscapes. Freshwater Biology 47: 541-557.

Doyle MW, Miller DE, Harbor JM. 1999. Should river restoration be based on classification schemes or process models? Insights from the history of geomorphology? ASCE International Conference on Water Resources Engineering, Seattle, Washington, USA.

Eaton BC, Church M, Millar RG. 2004. Rational regime model of alluvial channel morphology and response. Earth Surface Processes and Landforms 29: 511-529.

Egozi R, Ashmore P. 2008. Defining and measuring braiding intensity. Earth Surface Processes and Landforms 33: 2121-2138.

Florsheim JL. 1985. Fluvial requirements for gravel bar formation in northwestern California. Master's thesis, Arcata, California, Humboldt State University.

Galay VJ, Kellerhals R, Bray DI. 1973. Diversity of river types in Canada. Fluvial Processes and Sedimentation. Proceedings of the Hydrology Symposium. National Research Council of Canada: 217-250.

Gregory KJ, Davis RJ. 1993. The perception of riverscape aesthetics: An example from two Hampshire rivers. Journal of Environmental Management 39: 171-185.

Greig SM, Richardson R, Gibson J. 2006. A new impact assessment tool to support river engineering regulatory decisions - Technical Report. Project No. WFD49, SNIFFER, Edinburgh, UK.

Howard AD, Keetch ME, Vincent CL. 1970. Topological and geometrical properties of braided streams. Water Resources Research 37: 3275-3283. 
Huang S-C L, Tassinary L. 2000. A study of people's perception of waterscapes in built environments. Journal of Public Affair Review 1: 1-19.

Hull RB, Stewart WP. 1992. Validity of photo-based scenic beauty judgments. Journal of Environmental Psychology 12: 101-114.

Ikeda H. 1975. On the bed configuration in alluvial channels: Their types and condition of formation with reference to bars. Geographical Review of Japan 48: $712-730$.

Ikeda H. 1977. On the origin of bars in the meandering channels: Bulletin of the Environmental Research Center, University of Tsukuba 1: 17-31.

Juracek KE, Fitzpatrick FA. 2003. Limitations and implications of stream classification. Journal of the American Water Resources Association 39 (3): 659-670.

Kellerhals R, Neill CR, Bray DI. 1972. Hydraulic and geomorphic characteristics of rivers in Alberta. Research Council of Alberta, River Engineering and Surface Hydrology Report 72: 1-52.

Kellerhals R, Church M, Bray DI. 1976. Classification and analysis of river processes. Journal of the Hydraulics Division ASCE 102: 813-829.

Kellerhals R, Church M. 1989. The morphology of large rivers: characterization and management. In Dodge, D.P. (Ed) Proceedings of the International Large River Symposium. Canadian Special Publication of Fisheries and Aquatic Sciences 106: 31-48.

Knighton AD, Nanson GC. 1993. Anastomosis and the continuum of channel pattern. Earth Surface Processes and Landforms 18: 613-625.

Kondolf GM. 1995. Geomorphological stream channel classification in aquatic habitat restoration: uses and limitations. Aquatic Conservation: Marine and Freshwater Ecosystems 5: 127-141.

Kondolf GM, Montgomery DR, Piégay H, Schmitt L. 2003. Geomorphic Classification of Rivers and Streams. In Kondolf, G.M. and Piégay, H (Eds) Tools in Fluvial Geomorphology, John Wiley \& Sons Ltd, Chichester, London.

Lane EW. 1957. A study of the shape of channels formed by natural streams flowing in erodible material. Missouri River Division Sediment Series No. 9, U.S. Army Engineering Division Missouri River, Corps of Engineers, Omaha, Nebraska.

Le Lay YF, Piégay H, Gregory K, Chin A, Dolédec S, Elosegi A, Mutz M, Wyżga B, Zawiejska J. 2008. Variations in cross-cultural perception of riverscapes in relation to in-channel wood. Transactions of the Institute of British Geographers 33(2): 268-287.

Leopold LB, Wolman MG. 1957. River channel patterns: braided, meandering and straight. U.S. Geological Society Professional Paper 282-B. 
Makaske B. 2001. Anastomosing rivers: a review of their classification, origin and sedimentary products. Earth Surface Review 53: 149-196.

Milner VS. 2010. Assessing the performance of morphologically based river typing in Scotland using a geomorphological and ecological approach. PhD thesis, University of Stirling, Stirling, UK.

Mollard JD. 1973. Air photo interpretation of fluvial features. Fluvial Processes and Sedimentation. Research Council of Canada: 341-380.

Montgomery DR, Buffington JM. 1997. Channel-reach morphology in mountain drainage basins. Geological Society of America Bulletin, 109: 596-611.

Montgomery DR, Buffington JM. 1998. Channel Processes, Classification and Response. In Naiman, R. and Bilby, R. (Eds) River Ecology and Management: Lessons from the Pacific Coastal Ecoregion, New York, NY: Springer-Verlag.

Mosley MP. 1987. The classification and characterization of rivers In Richards K. (ed) River Channels, Environment and Processes, Blackwell, Oxford: 295-320.

Mosley MP. 1989. Perception of New Zealand river scenery. New Zealand Geographer 45: 2-13.

Nanson GC, Knighton AD. 1996. Anabranching rivers: their causes, character and classification. Earth Surface Processes and Landforms 21 (3): 217-239.

Piégay H, Gregory KJ, Bondarev V, Chin A, Dahlstrom N, Elosegi A, Gregory SV, Joshi V, Mutz M, Rinaldi M, Wyzga B. Zawiejska J. 2005. Public Perception as a Barrier to Introducing Wood in Rivers for Restoration Purposes. Environmental Management, 36 (5): 665-674.

Randolph JJ. 2008. Online Kappa Calculator. Available at: http://justus.randolph.name/kappa [08/11/2010].

Robert A. 2003. River Processes: An Introduction to Fluvial Dynamics, Arnold, London, UK.

Rosgen DL. 1994. A classification of natural streams. Catena, 22: 169-199.

Scott A, Clarke R. 2000. Multivariate Techniques. In Sparks, T. (Eds) Statistics in Ecotoxicology, John Wiley \& Sons Ltd, Chichester, UK: 149-178.

Siegel S, Castellan NJ. 1988. Nonparametric statistics for the Behavioural Sciences (Second edition). McGraw-Hill Book Company, New York.

Shuttleworth S. 1980. The use of photographs as an environment presentation medium in landscape studies. Journal of Environmental Management 11: 61-76. 
Smith DG, Smith ND. 1980. Sedimentation in anastomosed river systems: examples from alluvial valleys neat Banff, Alberta. Journal of Sedimentary Petrology 50 (1): 157-158.

Snelder TH, Weatherhead M, O’Brien R, Shankar U, Biggs BJF, Mosley P. 1999. Further development and application of a GIS based river environment classification system, National Institute of Water \& Atmospheric Research Ltd, Project No: NRX905.

Snelder TH, Biggs BJF. 2002. Multiscale River Environment Classification for Water Resources Management. Journal of the American Water Resources Association 38 (5): $1225-1239$.

Sukegawa N. 1973. Condition for the formation of alternate bars in straight alluvial channels In Proceedings of the international symposium on river mechanics, Bangkok, Thailand, International Association for Hydraulic Research A58-1-A5811.

Ter Braak CJF. 1986. Canonical Correspondence Analysis: A New Eigenvector Technique for Multivariate Direct Gradient Analysis. Ecology 67 (5): 1167-1179.

Ter Braak CJF, Smilauer P. 1998. CANOCO Reference Manual and User's Guide to CANOCO for Windows: Software for Canonical Community Ordination (version 4). Microcomputer Power, Ithaca, New York, USA.

Thorne CR. 1997. Channel types and morphological classification. In Thorne CR, Hey RD, Newson MD (Eds) Applied Fluvial Geomorphology for River Engineering and Management, John Wiley \& Sons: 175-222.

Vining J, Orland B. 1989. The video advantage: a comparison of two environmental representation techniques. Journal of Environmental Management 29: 275-283. 
Tables

Table 1: Geomorphic summary of channel types in the SEPA typology (modified from Greig et al. 2006).

Table 2: Percentage of respondents selecting a channel type per photograph. Numbers in bold indicate the most common channel type chosen per photograph. See Table 1 for channel codes.

Table 3: Mean percentage of respondents per channel type.

Table 4: The combined view of three professional geomorphologists and the global view of respondents. See Table 1 for channel codes.

Table 5: Number of channel types chosen by respondents from different disciplines.

Table 6: The most common channel type chosen by respondents of different disciplinary backgrounds. See Table 1 for channel codes.

Table 7: Number of channel types chosen per photograph by respondents with different levels of experience in classification systems.

Table 8: The most common chosen channel type by respondents of different levels of experience in classification systems. See Table 1 for channel codes. 


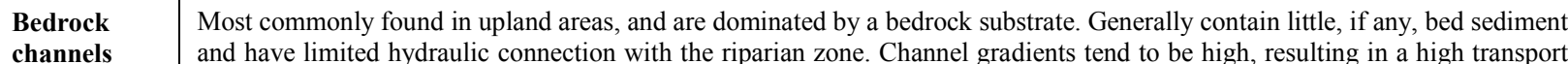
capacity but limited sediment supply.

(B)

Cascades (C) $\quad$ cobbles and boulders constrained by confining valley walls. The riparian zone is usually extremely small in extent. The large

Are restricted to upland areas with steep slopes and are characterised by disorganised bed material typically consisting of size of bed material, high levels of energy dissipation due to the bed roughness, dictate that the bed only becomes mobile in extreme floods (ca. $>25$ year return interval). Bedrock outcrops are common, and small pools may be present among the boulders.

Step-pool $\quad$ Step-pool channels have a steep gradient and consist of large boulder clasts which form discrete sediment accumulations channels across the channel, forming a series of "steps" which are separated by intervening pools containing finer sediment. The (S) $\quad$ stepped channel morphology results in zones of turbulence interspersed by more tranquil flows. High channel roughness and large bed material results in stable channels that respond only to very large flood events. The stream is generally confined by the valley sides.

Plane bed $\quad$ Generally moderate gradient streams with relatively featureless gravel/cobble beds, but include units ranging from glides, $\begin{array}{lll}\text { channels } & \text { riffles and rapids. Sediment size and channel gradients are smaller than step-pool channels and deeper pool sections tend to be }\end{array}$ (P) lacking. The river bed is generally armoured and, thus, mobilized in larger floods. Although channels are typically stable, they are more prone to channel change than any of the preceding channel types. Thus, with relatively more frequent bedload movement, they represent transitional channels between the more stable types listed above and the following more dynamic types of channel. Channels are generally straight and may be confined or unconfined by the valley sides.

Pool-riffle $\quad$ Meandering and unconfined channels that are characterised by lateral oscillating sequences of bars, pools and riffles during channels $\quad$ low flow, resulting from oscillations in hydraulic conditions from convergent (erosive) to divergent (depositional) flow channels environments. The gradient of such channels is low-moderate and the width depth ratio high. The bed is predominantly gravel, (O) with occasional patches of cobbles and sand. Accumulation of sediments in gravel bars indicates increasingly transportlimited conditions, though most large floods will produce some bedload movement on an annual basis, thus reducing the stability of the channel The banks are typically resistant to erosion, and lateral migration of the channel is limited, resulting in relatively narrow and intermittently deep channels.

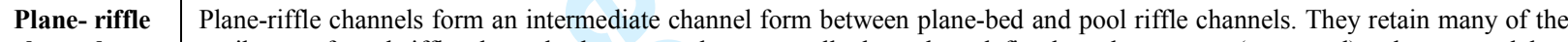
$\begin{array}{lll}\text { channels } & \text { attributes of pool-riffle channels, however, they generally have less defined pools, coarser (armoured) substrate and less }\end{array}$ (R) extensive bar features.

\section{Braided}

channels

(D) Braided reaches are characterised by relatively high gradients (but ones that are less than upstream reaches) and/or abundant bedload. Sediment transport is usually limited under most conditions and the channel splits into a number of threads around instream bars. Poor bank strength renders them highly dynamic and channels will generally change even in relatively small flood events.

Wandering These reaches exhibit characteristics of braided and meandering channels simultaneously, or if studies over a number of years, channel display a switching between divided and undivided channel types. Wandering channels may also be susceptible to channel (W) avulsions during high flow events, where the channel switches to a historical planform. Wandering channels typically occur where a reduction of bed material size and channel slope is combined with a widening of the valley floor.

Low $\quad$ Are unconfined low-gradient meandering channels with a bedload dominated by sand and fine gravel. Hence, the channel bed gradient has marked fine sediment accumulations that are mobile in most flood events. These occur in higher order (i.e. typically \begin{tabular}{l|l} 
actively & lowland settings). The fine bed sediment erodible banks and unconfined settings means that such channels are dynamic and
\end{tabular} meandering prone to change, they also often have extensive riparian zones and floodplains which are linked to the channel. Bars and pools (A)

Groundwate r dominated channels (G) may be present, and are associated with bends and crossing of the meander pattern.

\begin{tabular}{ll} 
(G) & $\begin{array}{l}\text { deposited sediments may remain in the gravel for extended periods, promoting the accumulation of large quantities of fine } \\
\text { sediment. Substrate generally comprises gravels, pebbles and sands, and glides and runs are the dominant flow types. }\end{array}$ \\
\hline $\begin{array}{l}\text { Low } \\
\text { gradient } \\
\text { passively } \\
\text { meandering } \\
\text { (M) }\end{array}$ & $\begin{array}{l}\text { These channels are typically found at lower extremities of the channel system. Generally they flow through resistant alluvium. } \\
\text { They are typically 'fixed' in there planform geometry, which is sinuous. These channels are often incised and display low } \\
\text { width depth ratios. The beds typically comprise fine sedimentary materials, although pockets of gravel can be present. These } \\
\text { channels are typically deep and flows are dominated by glides, although runs may be associated with meander bends. }\end{array}$ \\
\end{tabular}

Table 1: Geomorphic summary of channel types in the SEPA typology (modified from Greig et al. 2006). The letter in brackets indicates the code used for a channel type in subsequent analyses. 


\begin{tabular}{|c|c|c|c|c|c|c|c|c|c|c|c|c|c|c|}
\hline \multicolumn{15}{|c|}{ Channel type } \\
\hline $\begin{array}{l}\text { Photo- } \\
\text { graph }\end{array}$ & A & $\mathrm{B}$ & $\mathrm{D}$ & $\mathrm{C}$ & $\mathrm{G}$ & $\mathrm{M}$ & $\mathrm{P}$ & $\mathrm{R}$ & $\mathrm{O}$ & $\mathrm{S}$ & $\mathrm{W}$ & Other & $\begin{array}{l}\text { Didn't } \\
\text { specify }\end{array}$ & Total \\
\hline A & 67.37 & 0 & 0.98 & 0 & 0.98 & 11.22 & 3.41 & 2.44 & 10.73 & 0 & 3.9 & 0 & 0.98 & 100 \\
\hline B & 0 & 7.8 & 0 & 14.15 & 0.49 & 0 & 2.93 & 9.27 & 18.51 & 45.85 & 0 & 0 & 0.49 & 100 \\
\hline $\mathrm{C}$ & 2.93 & 0 & 75.12 & 0 & 0 & 1.95 & 1.46 & 1.46 & 0.49 & 0.49 & 15.61 & 0.49 & 0 & 100 \\
\hline $\mathrm{D}$ & 41.95 & 0 & 0.49 & 0 & 0 & 38.54 & 3.41 & 0.49 & 5.37 & 0 & 9.27 & 0.49 & 0 & 100 \\
\hline $\mathrm{E}$ & 1.46 & 3.9 & 0 & 1.95 & 0.49 & 0.49 & 16.1 & 33.66 & 38.05 & 3.41 & 0 & 0.49 & 0 & 100 \\
\hline $\mathrm{F}$ & 0.49 & 27.32 & 0 & 14.15 & 0.49 & 0 & 2.93 & 8.78 & 16.59 & 27.8 & 0 & 0.98 & 0.49 & 100 \\
\hline $\mathrm{G}$ & 0 & 73.17 & 0 & 15.12 & 0 & 0 & 1.46 & 0.98 & 4.39 & 4.88 & 0 & 0 & 0 & 100 \\
\hline $\mathrm{H}$ & 1.46 & 1.95 & 1.95 & 3.9 & 1.95 & 4.39 & 39.02 & 36.59 & 0.98 & 0 & 0.98 & 5.85 & 0.98 & 100 \\
\hline I & 6.34 & 2.44 & 55.12 & 0 & 0 & 3.41 & 1.46 & 9.76 & 1.46 & 0 & 17.07 & 1.95 & 0.98 & 100 \\
\hline $\mathrm{J}$ & 5.37 & 15.12 & 3.41 & 3.41 & 2.44 & 7.8 & 23.9 & 25.4 & 0.49 & 0.98 & 6.34 & 3.41 & 1.95 & 100 \\
\hline K & 0 & 10.24 & 0 & 36.1 & 0 & 0 & 0 & 0 & 1.46 & 52.2 & 0 & 0 & 0 & 100 \\
\hline $\mathrm{L}$ & 11.71 & 0 & 37.56 & 0 & 0.49 & 5.37 & 1.95 & 1.95 & 11.71 & 0 & 24.88 & 3.41 & 1.95 & 100 \\
\hline $\mathrm{M}$ & 16.1 & 0 & 2.44 & 0 & 4.88 & 17.56 & 9.76 & 30.24 & 8.78 & 0 & 6.83 & 2.44 & 0.98 & 100 \\
\hline $\mathrm{N}$ & 6.34 & 0 & 0 & 0.98 & 3.41 & 30.73 & 42.93 & 0.98 & 0.49 & 0 & 3.9 & 10.24 & 0 & 100 \\
\hline $\mathrm{O}$ & 0.49 & 66.34 & 0 & 17.56 & 0 & 0.49 & 1.46 & 1.46 & 2.44 & 9.27 & 0 & 0.49 & 0 & 100 \\
\hline$P$ & 0 & 11.71 & 0.98 & 36.59 & 0.49 & 0 & 0.49 & 4.39 & 10.73 & 32.68 & 0 & 1.46 & 0.49 & 100 \\
\hline Q & 19.02 & 8.29 & 3.9 & 1.46 & 6.34 & 10.73 & 17.07 & 25.85 & 2.93 & 0 & 2.44 & 1.46 & 0.49 & 100 \\
\hline $\mathrm{R}$ & 56.1 & 0 & 0 & 0.49 & 1.46 & 19.02 & 0.98 & 6.83 & 7.32 & 0.98 & 5.37 & 0.98 & 0.49 & 100 \\
\hline S & 0 & 9.76 & 0 & 31.22 & 0 & 0.49 & 0.49 & 0 & 6.83 & 49.27 & 0 & 1.95 & 0 & 100 \\
\hline
\end{tabular}

Table 2: Percentage of respondents selecting a channel type per photograph. Numbers in bold indicate the most common channel type chosen per photograph. See Table 1 for channel codes. 


\begin{tabular}{ll}
\hline Channel type & $\begin{array}{l}\text { Mean percentage } \\
\text { of respondents }\end{array}$ \\
\hline Bedrock & 69.76 \\
Braided & 56.95 \\
Active & 53.66 \\
Step-pool & 43.78 \\
Plane-bed & 40.98 \\
Pool-riffle & 38.05 \\
Cascade & 36.59 \\
Plane-riffle & 27.16 \\
\hline
\end{tabular}

Table 3: Mean percentage of respondents per channel type.

\begin{tabular}{llll}
\hline $\begin{array}{l}\text { Photo- } \\
\text { graph }\end{array}$ & $\begin{array}{l}\text { Professional } \\
\text { judgement }\end{array}$ & $\begin{array}{l}\text { Global } \\
\text { view }\end{array}$ & Agreement \\
\hline A & A & A & $=$ \\
B & S & B & $=$ \\
C & W & D & x \\
D & A & A & $=$ \\
E & R & O & x \\
F & B & S & X \\
G & B & B & $=$ \\
H & P & P & $=$ \\
I & W & D & x \\
J & P & R & X \\
K & S & S & $=$ \\
L & W & D & x \\
M & R & R & $=$ \\
N & M & P & x \\
O & B & B & $=$ \\
P & S & C & x \\
Q & R & R & $=$ \\
R & A & A & $=$ \\
S & S & S & $=$ \\
\hline
\end{tabular}

Table 4: The combined view of three professional geomorphologists and the global view of respondents. See Table 1 for channel codes. 


\begin{tabular}{llll} 
& & \multicolumn{2}{l}{ Discipline/career } \\
\cline { 2 - 4 } & & & $\begin{array}{l}\text { Practitioners } \\
\text { involved in } \\
\text { Photograph }\end{array}$ \\
& $\begin{array}{l}\text { Earth } \\
\text { sciences }\end{array}$ & $\begin{array}{l}\text { Ecological } \\
\text { sciences }\end{array}$ & $\begin{array}{l}\text { river } \\
\text { conservation } \\
\text { and }\end{array}$ \\
& & & management \\
\hline A & 7 & 6 & 5 \\
B & 6 & 7 & 5 \\
C & 8 & 6 & 4 \\
D & 7 & 5 & 6 \\
E & 8 & 5 & 7 \\
F & 7 & 6 & 8 \\
G & 3 & 4 & 4 \\
H & 8 & 9 & 6 \\
I & 9 & 9 & 6 \\
J & 12 & 10 & 9 \\
K & 4 & 4 & 2 \\
L & 7 & 9 & 6 \\
M & 9 & 7 & 8 \\
N & 8 & 7 & 6 \\
O & 8 & 7 & 3 \\
P & 6 & 5 & 7 \\
Q & 9 & 10 & 9 \\
R & 6 & 7 & 6 \\
S & 7 & 5 & 3 \\
\hline Mean & 7.3 & 6.7 & 5.8 \\
Std dev & 1.9 & 1.9 & 2 \\
\hline & & & \\
\hline
\end{tabular}

Table 5: Number of channel types chosen by respondents from different disciplines/careers. 


\begin{tabular}{|c|c|c|c|c|c|}
\hline \multicolumn{6}{|c|}{ Discipline/career } \\
\hline \multicolumn{2}{|c|}{ Earth sciences } & \multicolumn{2}{|c|}{ Ecological sciences } & \multicolumn{2}{|c|}{$\begin{array}{c}\text { Practitioners involved in } \\
\text { river conservation and } \\
\text { management }\end{array}$} \\
\hline $\begin{array}{l}\% \text { of } \\
\text { respondents }\end{array}$ & $\begin{array}{l}\text { Dominant } \\
\text { channel type }\end{array}$ & $\begin{array}{l}\% \text { of } \\
\text { respondents }\end{array}$ & $\begin{array}{l}\text { Dominant } \\
\text { channel type }\end{array}$ & $\begin{array}{l}\% \text { of } \\
\text { respondents }\end{array}$ & $\begin{array}{l}\text { Dominant } \\
\text { channel type }\end{array}$ \\
\hline 69.9 & A & 68.2 & A & 58.5 & A \\
\hline 55.4 & $\mathrm{~S}$ & 31.8 & S & 50.9 & S \\
\hline 77.1 & $\mathrm{D}$ & 75.8 & $\mathrm{D}$ & 75.5 & $\mathrm{D}$ \\
\hline 44.6 & A & 43.9 & $\mathrm{M}$ & 56.6 & A \\
\hline 49.4 & $\mathrm{O}$ & 40.9 & $\mathrm{R}$ & 30.2 & $\mathrm{R}$ \\
\hline 31.3 & B & 30.3 & $\mathrm{~S}$ & 30.2 & B \\
\hline 81.9 & B & 72.7 & B & 64.2 & B \\
\hline 47 & $\mathrm{P}$ & 47 & $\mathrm{R}$ & 39.6 & $\mathrm{P}$ \\
\hline 65.1 & D & 39.4 & $\mathrm{D}$ & 62.3 & D \\
\hline 31.3 & $\mathrm{R}$ & 24.2 & $\mathrm{P}$ & 24.5 & $\mathrm{P}$ \\
\hline 49.4 & $\mathrm{~S}$ & 57.6 & $\mathrm{~S}$ & 52.8 & $\mathrm{~S}$ \\
\hline 50.6 & D & 45.5 & $\mathrm{D}$ & 37.7 & $\mathrm{~W}$ \\
\hline 26.5 & $\mathrm{R}$ & 39.4 & $\mathrm{R}$ & 26.4 & $\mathrm{R}$ \\
\hline 39.8 & $\mathrm{P}$ & 54.5 & $P$ & 39.6 & M \\
\hline 75.9 & B & 57.6 & B & 66 & B \\
\hline 38.6 & $\mathrm{C}$ & 31.8 & $\mathrm{C}$ & 41.5 & $\mathrm{C}$ \\
\hline 28.9 & $\mathrm{R}$ & 25.8 & $\mathrm{R}$ & 22.6 & $\mathrm{R}$ \\
\hline 60.2 & A & 54.5 & A & 54.7 & A \\
\hline 60.2 & $\mathrm{~S}$ & 40.9 & $\mathrm{C}$ & 54.7 & $\mathrm{~S}$ \\
\hline 51.7 & & 46.4 & & 46.8 & \\
\hline 17.0 & & 15.2 & & 15.7 & \\
\hline
\end{tabular}

Table 6: The most common channel type chosen by respondents of different disciplinary backgrounds. See Table 1 for channel codes. 


\begin{tabular}{lllll} 
& & \multicolumn{3}{c}{ Level of experience } \\
\cline { 3 - 5 } $\begin{array}{l}\text { Photo- } \\
\text { graph }\end{array}$ & $\begin{array}{l}\text { Channel type } \\
\text { (global view) }\end{array}$ & High & Moderate & Low \\
\hline A & Active meandering & 3 & 7 & 8 \\
B & Bedrock & 3 & 7 & 8 \\
C & Braided & 3 & 5 & 7 \\
D & Active meandering & 5 & 5 & 6 \\
E & Pool-riffle & 7 & 5 & 9 \\
F & Step-pool & 5 & 8 & 8 \\
G & Bedrock & 3 & 5 & 5 \\
H & Plane-bed & 5 & 6 & 10 \\
I & Braided & 5 & 8 & 9 \\
J & Plane-riffle & 8 & 10 & 11 \\
K & Step-pool & 3 & 5 & 3 \\
L & Braided & 5 & 7 & 9 \\
M & Plane-riffle & 7 & 9 & 9 \\
N & Plane-bed & 5 & 6 & 8 \\
O & Bedrock & 5 & 6 & 7 \\
P & Cascade & 5 & 5 & 7 \\
Q & Plane-riffle & 6 & 10 & 10 \\
R & Active meandering & 4 & 6 & 8 \\
S & Step-pool & 3 & 5 & 7 \\
\hline & Mean & 4.7 & 6.6 & 7.9 \\
& Standard deviation & 1.5 & 1.7 & 1.9 \\
\hline & & & &
\end{tabular}

Table 7: Number of channel types chosen per photograph by respondents with different levels of experience in classification systems. 


\begin{tabular}{|c|c|c|c|c|c|c|}
\hline \multirow[b]{3}{*}{ Photograph } & \multicolumn{6}{|c|}{ Level of experience in classification systems } \\
\hline & \multicolumn{2}{|c|}{ High } & \multicolumn{2}{|c|}{ Moderate } & \multicolumn{2}{|c|}{ Low } \\
\hline & $\begin{array}{l}\% \text { of } \\
\text { respondents }\end{array}$ & $\begin{array}{l}\text { Dominant } \\
\text { channel } \\
\text { type }\end{array}$ & $\begin{array}{l}\% \text { of } \\
\text { respondents }\end{array}$ & $\begin{array}{l}\text { Dominant } \\
\text { channel } \\
\text { type }\end{array}$ & $\begin{array}{l}\% \text { of } \\
\text { respondents }\end{array}$ & $\begin{array}{l}\text { Dominant } \\
\text { channel } \\
\text { type }\end{array}$ \\
\hline A & 67.7 & A & 58.8 & A & 71.3 & A \\
\hline B & 67.7 & $\mathrm{~S}$ & 46.3 & $\mathrm{~S}$ & 40.4 & $\mathrm{~S}$ \\
\hline $\mathrm{C}$ & 64.5 & $\mathrm{D}$ & 71.3 & $\mathrm{D}$ & 81.9 & $\mathrm{D}$ \\
\hline D & 51.6 & A & 45 & M & 40.4 & A \\
\hline $\mathrm{E}$ & 45.2 & $\mathrm{O}$ & 42.5 & $\mathrm{O}$ & 31.9 & $\mathrm{O}$ \\
\hline $\mathrm{F}$ & 54.8 & B & 33.8 & B & 34 & $\mathrm{~S}$ \\
\hline G & 87.1 & B & 60 & B & 79.8 & B \\
\hline $\mathrm{H}$ & 35.5 & $\mathrm{P}$ & 42.5 & $\mathrm{P}$ & 39.4 & $\mathrm{R}$ \\
\hline I & 45.2 & W & 58.8 & D & 60.6 & $\mathrm{D}$ \\
\hline $\mathrm{J}$ & 32.3 & $\mathrm{P}$ & 30 & $\mathrm{P}$ & 28.7 & $\mathrm{R}$ \\
\hline K & 45.2 & $\mathrm{~S}$ & 52.5 & $\mathrm{~S}$ & 51.1 & $\mathrm{~S}$ \\
\hline $\mathrm{L}$ & 41.9 & D & 51.3 & D & 28.7 & $\mathrm{D}$ \\
\hline M & 35.5 & A & 36.3 & $\mathrm{R}$ & 27.7 & $\mathrm{R}$ \\
\hline $\mathrm{N}$ & 58.1 & M & 51.3 & $\mathrm{P}$ & 38.3 & $\mathrm{P}$ \\
\hline $\mathrm{O}$ & 67.7 & B & 75 & B & 58.5 & B \\
\hline $\mathrm{P}$ & 41.9 & $\mathrm{~S}$ & 41.3 & $\mathrm{C}$ & 36.2 & $\mathrm{C}$ \\
\hline Q & 38.7 & A & 27.5 & $\mathrm{R}$ & 27.7 & $\mathrm{R}$ \\
\hline $\mathrm{R}$ & 71 & A & 53.8 & A & 53.2 & A \\
\hline S & 61.3 & $\mathrm{~S}$ & 55 & $\mathrm{~S}$ & 37.2 & $\mathrm{~S}$ \\
\hline Mean & 53.3 & & 49.1 & & 45.6 & \\
\hline Std dev & 15.0 & & 12.8 & & 17.4 & \\
\hline
\end{tabular}

Table 8: The most common chosen channel type by respondents of different levels of experience in classification systems. See Table 1 for channel codes. 


\section{Figures}

Figure 1: Channel types of Montgomery and Buffington shown as a function of transport capacity to relative sediment supply (reproduced from Montgomery and Buffington, 1997).

Figure 2: Photographs of streams and rivers used in the photo-questionnaire.

Figure 3: Channel typology flow diagram (Jeffries, 2009).

Figure 4: Principal component bi-plot of the distribution of photographs (labelled A to S) and channel types in the SEPA typology.

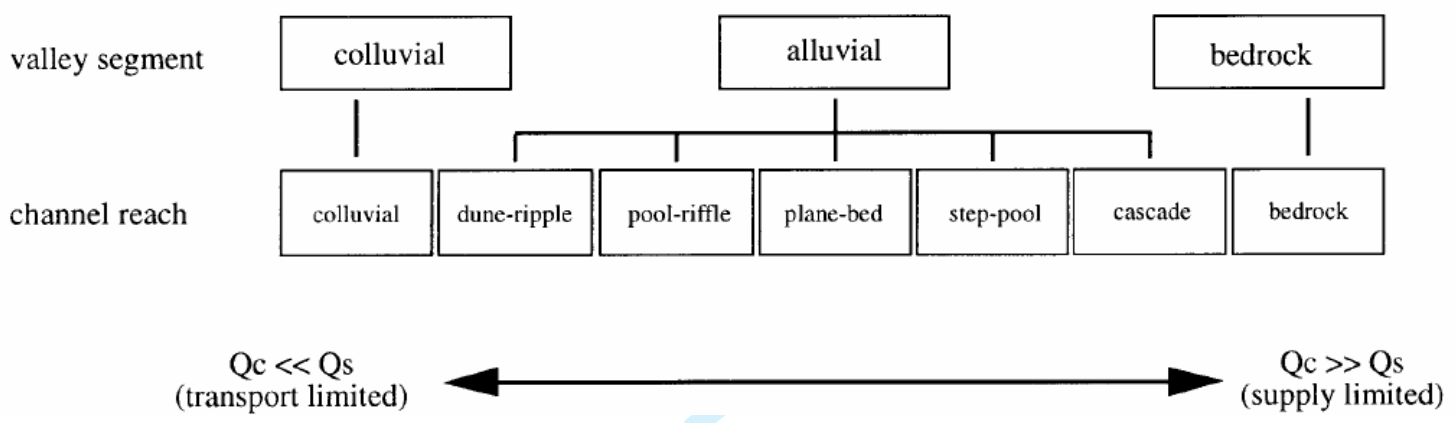

Figure 1: Channel types of Montgomery and Buffington shown as a function of transport capacity to relative sediment supply (reproduced from Montgomery and Buffington, 1997). 

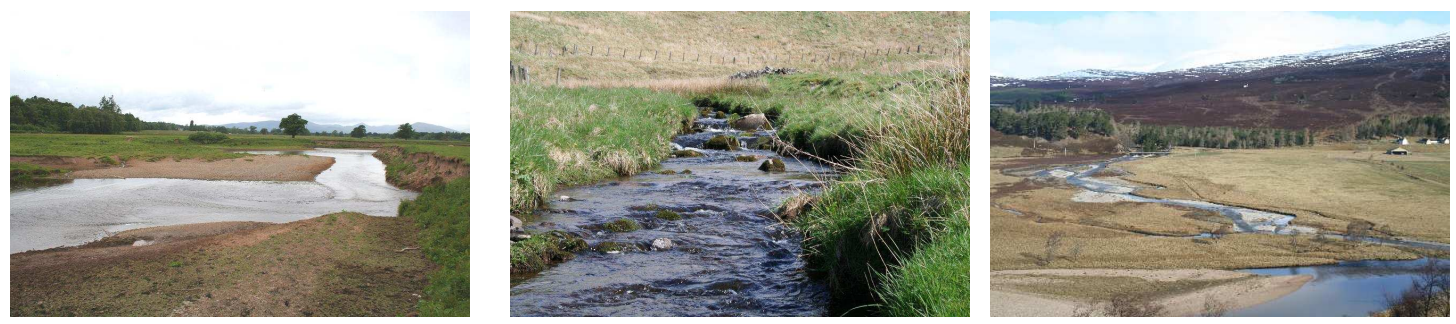

A

B

C
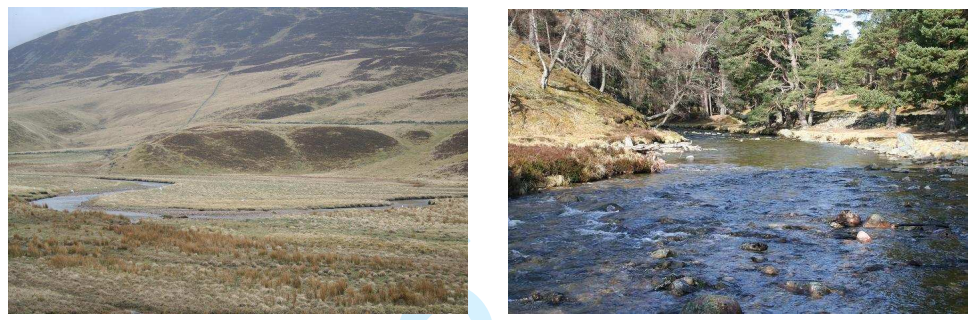

D

E
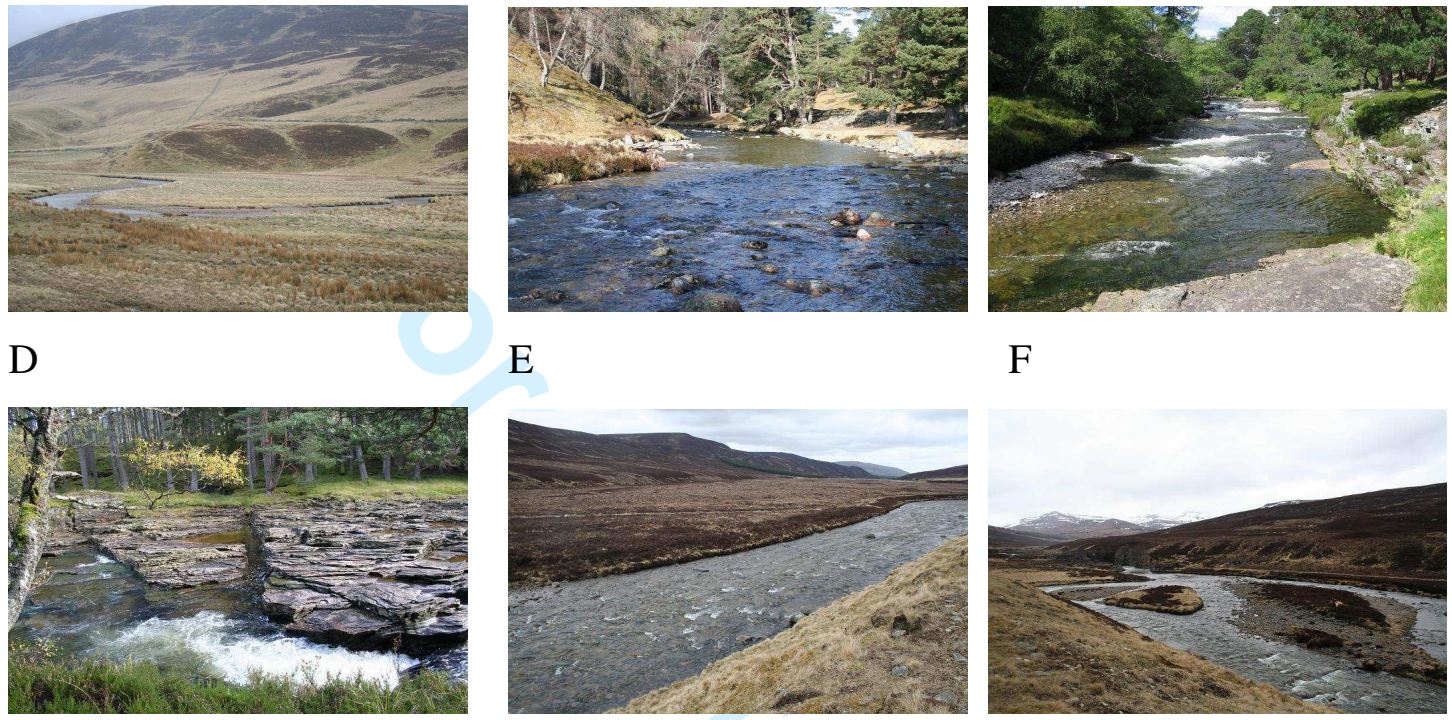

F

G

$\mathrm{H}$
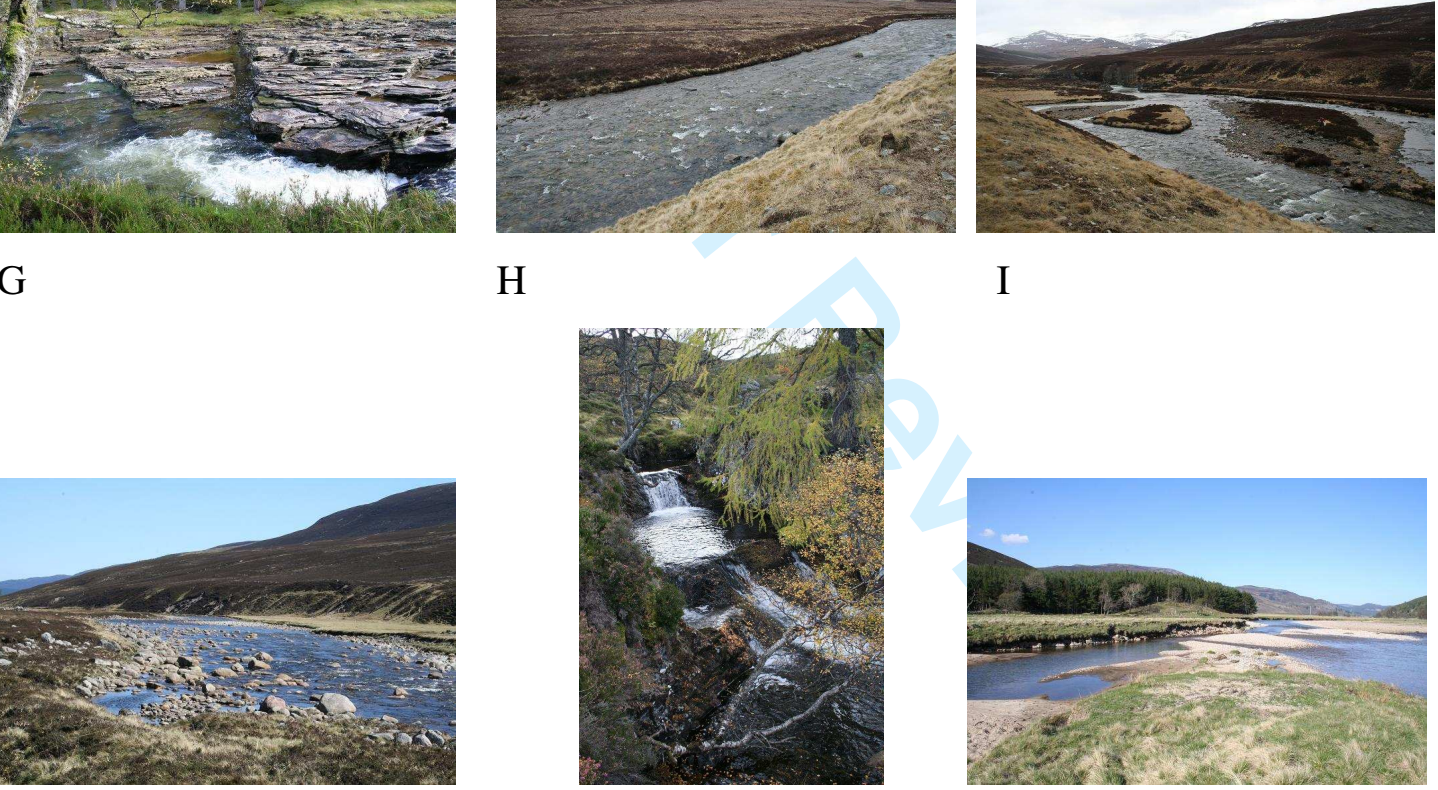

K

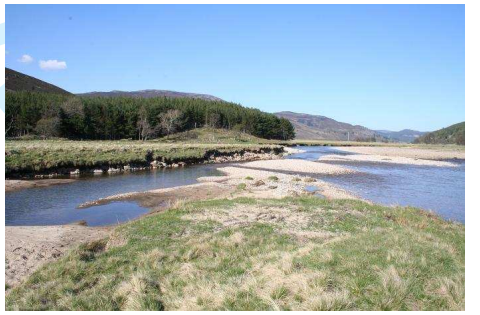

J

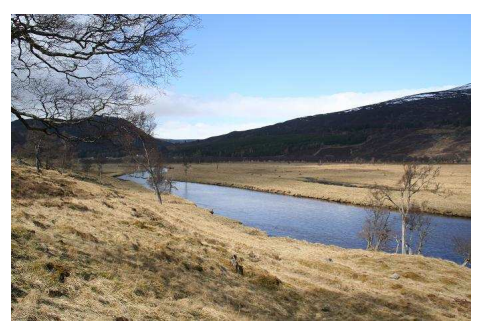

I

$\mathrm{L}$

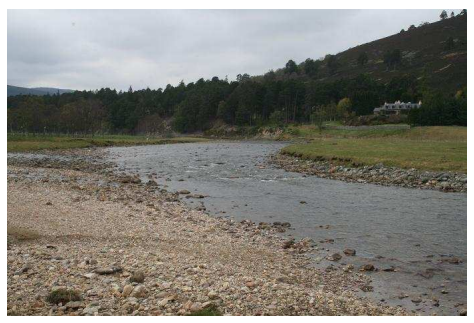

M

$\mathrm{N}$

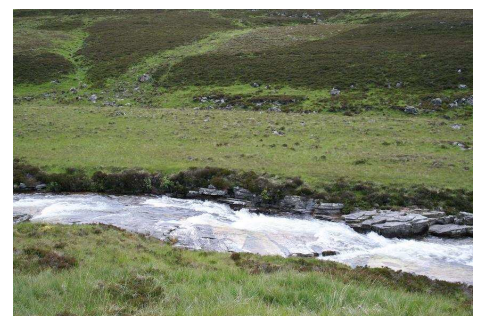

$\mathrm{O}$ 

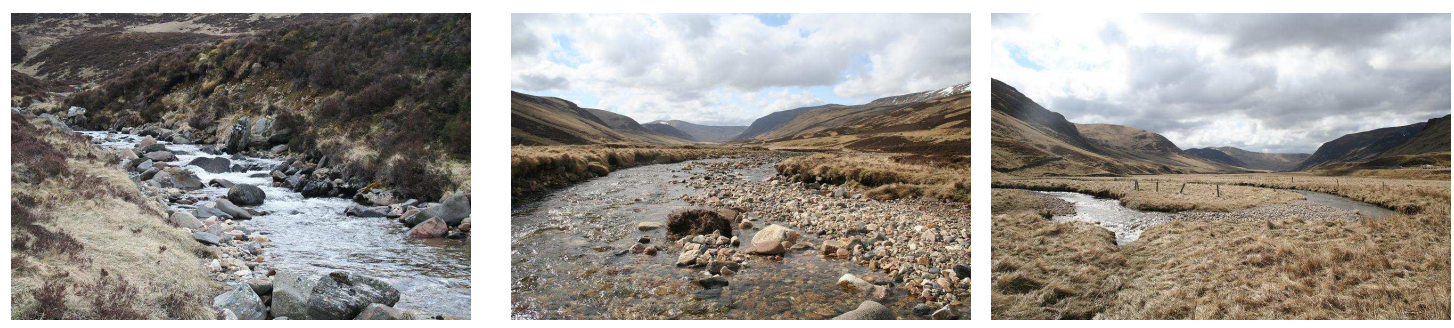

$\mathrm{P}$

Q

$\mathrm{R}$

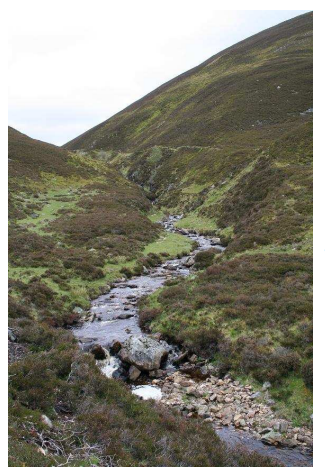

S

Figure 2: Photographs of streams and rivers used in the photo-questionnaire. 
Is there more than one kind of bed form or flow type ? (i.e. is the channel morphologically diverse?) Yes L

Does the main channel braid into 2 or more channels across mobile gravel bars that are bare or dominated by pioneer species ?
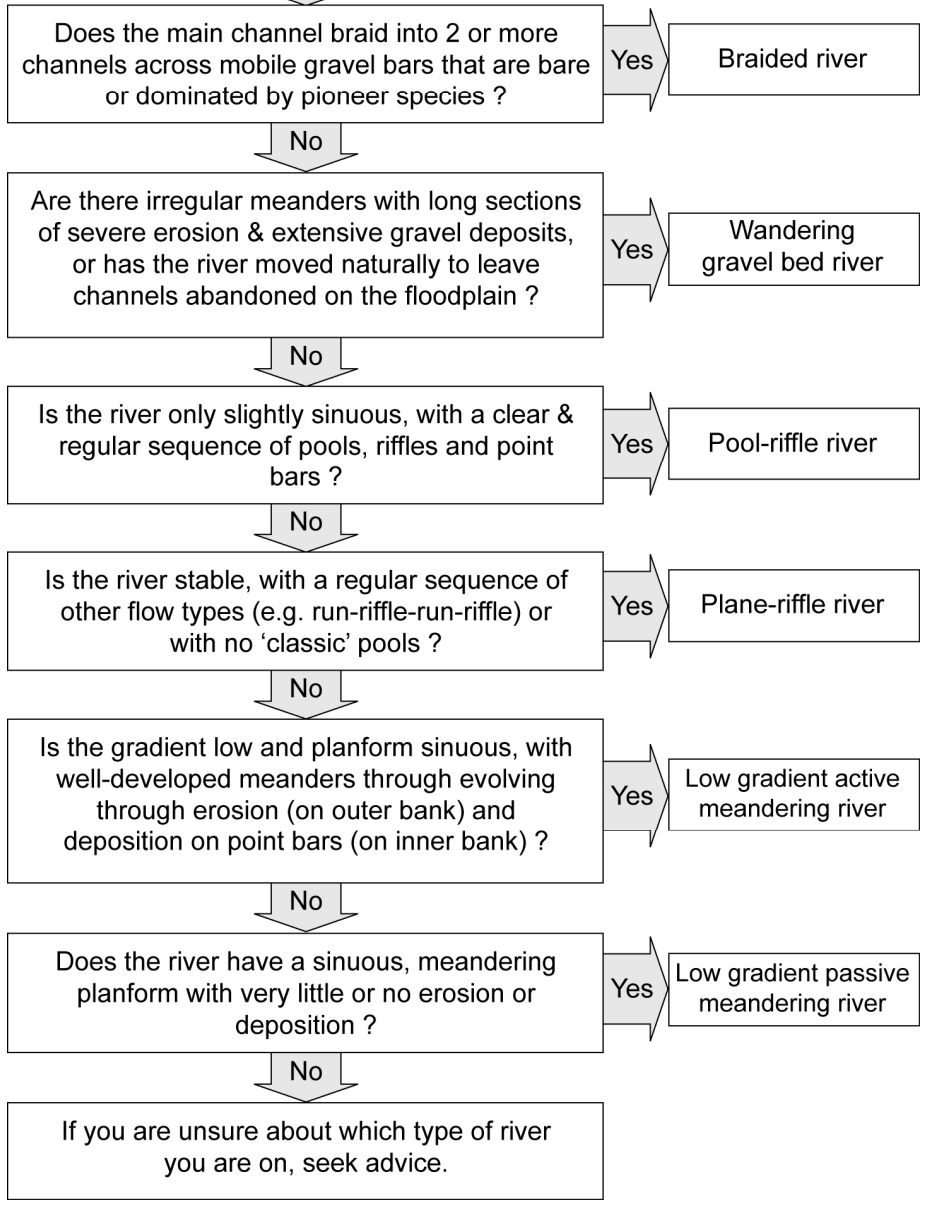

Figure 3: Channel typology flow diagram (Jeffries, 2009). 


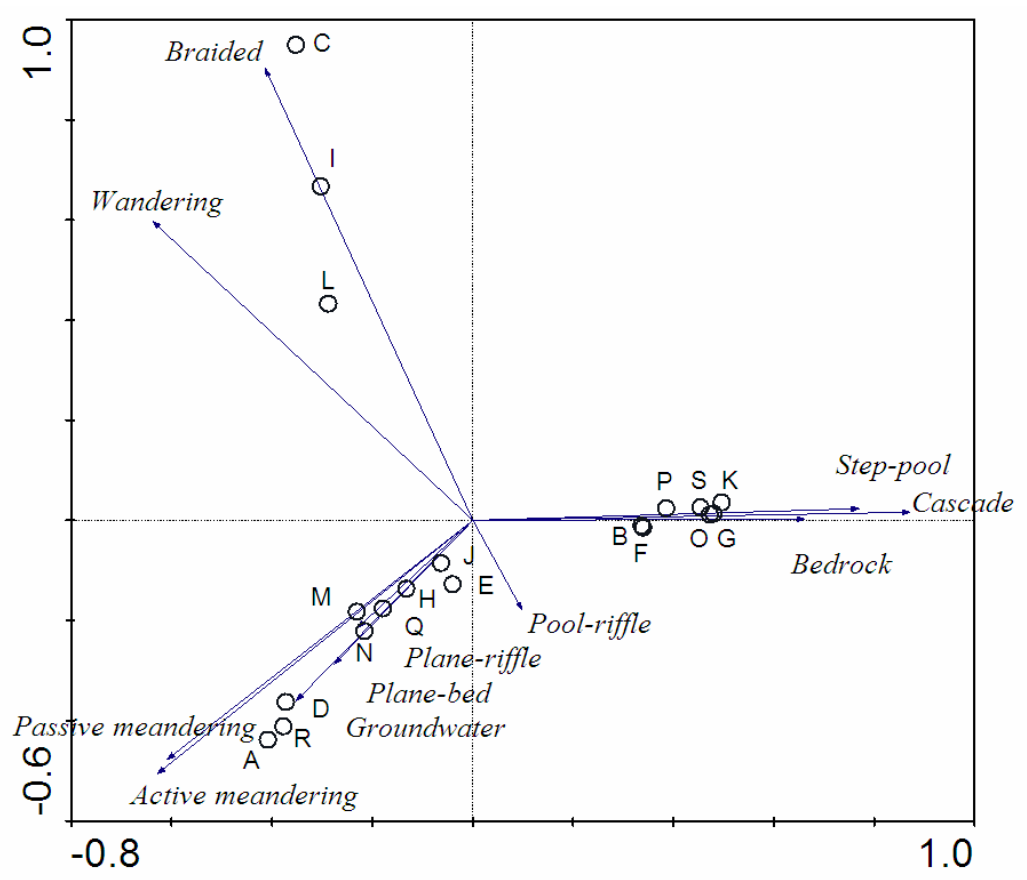

Figure 4: Principal component bi-plot of the distribution of photographs (labelled A to S) and channel types in the SEPA typology. 